\title{
ЖАНР АНТИУТОПІЇ В ЗАХІДНОСВРОПЕЙСЬКОМУ ТА АМЕРИКАНСЬКОМУ КІНЕМАТОГРАФІ 1926-1968 РОКІВ. ВИТОКИ, ФОРМУВАННЯ, РОЗВИТОК
}

\begin{abstract}
У статті досліджено появу та розвиток фільмів-антиутопій у період 1926-1968 рр. На иьому етапі розвитку фантастичного кінематографа антиутопії були відносно новаторським жанром, що виходив за рамки більш популярної пригодницької фантастики. Головну увагу приділено аналізу культурно-історичного контексту, що уможливлював виникнення подібних фільмів.
\end{abstract}

Ключові слова: фантастичне кіно, антиутопія, реалізм, модернізм, постмодерн.

В статье исследуется появление и развитие фильмов-антиутопий в период 1926-1968 г2. На данном этапе развития фантастического кинематографа антиутопии были сравнительно новаторским жанром, который выходил за рамки более популярной приключенческой фантастики. Внимание, главным образом, уделено анализу культурно-исторического контекста, который делал возможным появление подобных фильмов.

Ключевые слова: фантастическое кино, антиутопия, реализм, модернизм, постмодерн.

The thesis researches the development of dystopian films in 1918-1968 years. During that period of cinema development the dystopian films were an innovative genre, which stood out of the frame of more popular adventure science fiction films. The main focus of the thesis is the analysis of cultural and historical context which influenced the development of such films.

Key words: science fiction, dystopia, realism, modernism, postmodern.

Жанр антиутопії, що став поширеним явищем у літературі починаючи $31870-\mathrm{x}$ років $[3,291-$ 292], був відносно нечасто адаптованим до кінематографа до 1970-х років. На ранніх етапах свого існування кінематографічна фантастика розглядалась здебільшого як різновид пригодницького жанру, у якому фантастичні елементи виступали як екзотичне тло для розгортання сюжету. Крім цього, для модернізму, що змінив реалізм у кінематографі та домінування якого пов'язують з появою звукового кіно [14, 157], була характерною віра у науково-технічний та соціальний прогрес та можливість подолання негативних тенденцій сучасності, що зображувалися в антиутопіях. Через такі фактори, фільми-антиутопії епохи кінематографічного модерну могли з'являтися лише за умови сприятливих культурно-ідеологічних чинників у країнах їхнього виробництва. Зокрема, виробництво фільмів-антиутопій було неможливим у СРСР через офіційний ідеологічний постулат про побудову у майбутньому кращого суспільно-політичного устрою - комунізму, відповідно до чого радянське фантастичне кіно шукало інші жанрові форми, зокрема, адаптуючи естетику утопії. Такий аспект радянського кінематографа автор розглянув у окремій статті [5]. Натомість у західних демократичних країнах виробництво антиутопій залежало переважно від запитів глядачів на фільми 3 подібним баченням майбутнього. Відповідно до мети статті - простежити витоки жанру кінематографічної антиутопії, автор аналізує культурно-ідеологічний контекст створення та особливостей, що вплинули на сюжет та естетику подібних фільмів.

Стаття обмежується 1926-1968 роками. Нижня межа обумовлена створенням першого фільму-антиутопії. Верхня - політичними подіями 1968 року, що призвели до зміни модерної парадигми на постмодерну, збільшення популярності антиутопій та змінами у їх жанровій формі.

Тематика кінематографічної антиутопії відносно мало розглянута у науковій літературі. 3 одного боку, дослідники приділяють увагу аналізу художньої антиутопічної літератури, також на ній концентрується філософське осмислення жанру. 3 іншого боку, кінематографічні антиутопії осмислюються в рамках загальних праць, присвячених фантастичним фільмам, що призводить до розгля- 
ду їх як тематичної частини ширшого жанру кінофантастики. Натомість дослідницькі роботи, що зосереджуються на внутрішніх особливостях антиутопії як жанру, а також на історії його розвитку, на даний момент відсутні як у зарубіжній науковій літературі, так і у вітчизняній. Відповідно до цього, для аналізу витоків, історії формування та розвитку вказаного жанру, автор послуговується, насамперед, загальними працями 3 теорії та історії кіно, а також працями з теорії літератури.

Основою для періодизації кінематографічних антиутопій став розподіл кінематографічної на створені в рамках парадигм реалізм-модернізм-постмодерн, що досліджується у працях відомого дослідника культури Ф. Джеймісона, зокрема, у його книзі «Signatures of the Visible» [14]. Даною періодизацією культурних періодів так само послуговується дослідження П. Коатеса «Т The Gorgon's Gaze: German Cinema, Expressionism, and the Image of Horror», присвячене кіно німецького експресіонізму. Іншими працями, що висвітлюють історію німецького кінематографа зазначеного періоду та були залучені автором, стали праці німецьких авторів «Від Калігарі до Гітлера. Психологічна історія німецького кіна» 3. Кракауера, перекладена українською, та «Демонический экран» Л. Айснер, перекладена російською мовою. Також була використана праця відомого психоаналітика та дослідника культури Е. Фромма «Бегство от свободы», яка концентрується на феномені отримання задоволення від підкорення авторитарним режимам, що, зокрема, було притаманне масовій психології німців у період розвитку кінематографічного експресіонізму.

Серед загальних праць 3 історії кіно автор використав книжку радянського дослідника кінофантастики Ю. Ханютіна «Реальность фантастического мира», а також збірку «Фільм жахів. Горор», присвячену осмисленню розглянутого жанру, що опосередковано впливав на розвиток фантастичного кіно, розширюючи його рамки поза пригодницькою фантастикою, котра домінувала на ранніх етапах розвитку кіноіндустрії. Крім цього, була використана англомовна праця «Educational institutions in Horror Films» авторства А. Грюнцке, присвячена розвиткові фільму жахів та його зв'язку з науковим прогресом та страхом перед ним, що також було одним 3 основних мотивів, поширених в антиутопіях. Інша використана праця 3 дослідження фільмів жахів - книжка «Uncanny Bodies. The coming of the sound film and the origins of the horror genre» Р. Спардоні, про ранній етап розвитку цього жанру.
Серед загальних праць з історії кінематографа також були використані англомовні дослідження «In the Nick of Time. Motion picture sound serials» В. Клайна та «Epics, Spectacles, and Blockbusters: A Hollywood History» C. Нілла та С. Холла. Серед досліджень жанру антиутопії з позицій філософії та літературної теорії залучено праці радянських дослідників «В мире утопии: Пять диалогов об утопии, утопическом сознании и утопических экспериментах» Е. Баталова та «Что такое фантастика?» Ю. Кагарлицького. Крім цього, автор також посилається на збірку есеїв письменника-антиутопіста Дж. Оруелла «All art is propaganda: critical essays», у окремих $з$ яких письменник осмислював жанр, у якому працював.

Також використана література, присвячена вужчим питанням теорії та історії кінематографа. Одним 3 них $є$ колективна праця «British Science Fiction Cinema» за редакцією I. Хантера, що зосереджується на аналізі британського фантастичного кінематографа. Натомість праця I. Гріна «Planet of the Apes As American Myth : Race, Politics, and Popular Culture» розглядає кінематографічну франшизу «Планета мавп», перший фільм з якої став родоначальником антиутопії в американському кіно. Інші дві праці — «Godard and Counter Cinema: Vent d'Est» за авторством П. Воллена та «Vent d'Est, or Godard and Rocha At The Crossroads» Дж. Макбіна присвячені аналізу режисерського стилю Ж.-Л. Годара, який став автором одного 3 відносно ранніх фільмів-антиутопій.

Започаткування жанру фантастики у кінематографі пов'язують зі стрічкою «Мандрівка на Місяць» (Le Voyage dans la lune; 1902) режисера Ж. Мельєса $[8,5]$. Завдяки використанню у сценаpiї цієї картини фантастичного винаходу — гармати, що здатна перенести людей на Місяць у снаряді, герої фільму потрапляли у екзотичне середовище, що урізноманітнювало сюжетні та естетичні можливості пригодницького жанру. Подібний підхід до фантастики загалом був характерним для кінематографа більшості країн у першій половині XX століття. Виняток становила німецька кінофантастика, що ще у 1910-х роках почала використовувати химерні образи у кінострічках [4, 34]. 3 одного боку, така відмінність пов'язана 3 національною культурою Німеччини більш раннього періоду, що часто використовувала містичні образи, котрі викликали відчуття страху в літературі та інших формах мистецтва $[1,49-50] .3$ iншого боку, після поразки у Першій світовій війні, у Німеччині розпочинаються соціокультурні процеси, котрі підвищують запит на використання 
подібних елементів, зокрема і в кінематографі, та сприяють їх переосмисленню.

Повоєнний стан німецького суспільства характеризувався глибокою кризою, пов'язаною 3 військовою поразкою і відсутністю суттєвих змін у політичній системі та впевненості у власному майбутньому. Цей комплекс суспільних уявлень тогочасного німецького суспільства став об'єктом дослідження соціологів «Франкфуртської школи», зокрема, Т. Адорно та М.Горкгаймера, та у пізніший період був названий їхнім колегою Е. Фроммом «втечею від свободи» та описаний у його однойменній праці [7]. Феномен «втечі від свободи» полягав у страху індивідів перед можливістю вільного вибору через психологічний дискомфорт, який подібний вибір може дати, відповідно до чого ці індивіди знаходять задоволення у підкоренні зовнішній відносно до них владі, котра може набувати різних форм - від повного слідування жорстким релігійним догмам до підтримки встановлення диктатури [7, 123-124; 146-148]. У контексті німецького кінематографа 1920-х такий феномен набуває форми задоволення глядача переглядом стрічок, що сповнені підкоренням їх героїв зовнішнім факторам, на кшталт тиранії, волі антагоніста або долі $[4,104-105]$. Така соціально-психологічна тенденція створює новий тип задоволення від кіно, не притаманний іншим фільмам цього періоду.

Кінокартиною, що мала надзвичайно великий вплив як на німецький кінематограф 1920-х, так і на подальший розвиток фільмів жахів, стала стрічка Р. Віне «Кабінет доктора Калігарі» [6, 34] (Das Cabinet des Dr. Caligari; 1920). За першопочатковим задумом сценаристів фільму Г. Яновіца та К. Майєера, через метафоричне ототожнення 3 головним антагоністом картина мала піднімати питання сваволі влади, проте, через орієнтацію кінематографа на комерційний успіх, це послання було замінене на зображення більш прийнятної та менш політично контроверсійної для аудиторії історії, а саме - інтерпретація злочинів доктора Калігарі як породження уяви пацієнта психіатричної лікарні [4, 80-81]. Мотиви сумніву у реальності часто простежувалися у пізніших фільмах-антиутопіях, так само як і занепокоєння сильною владою, що гнобить індивіда.

Відразу за «Кабінетом доктора Калігарі» у Німеччині з'являється ціла низка фільмів, що так чи інакше експлуатують тематику тиранії $[4,92]$. Проте більшість 3 них зображували тиранію віддаленою у середньовічне минуле або стосувалась екзотичних для аудиторії країн Сходу [4, 95-96;
102]. Натомість у 1922 році була створена кінокартина «Доктор Мабузе, гравець» (Dr. Mabuse, der Spieler) режисера Ф. Ланга, який також брав участь у розробці сценарію «Кабінета доктора Калігарі». Персонаж доктора Мабузе використовував методи психоаналізу та гіпнозу задля досягнення абсолютного контролю над власними жертвами, відповідно до чого зміщується акцент від тематики страху перед містичними створіннями та екзотичних тираній до уявлення про можливість існування абсолютного контролю над індивідом у самій Німеччині та з використанням наукових досягнень, що наближало тематику даних фільмів до антиутопій. Ще однією схожістю обох фільмів 3 пізнішими кінематографічними антиутопіями була експлуатація параноїдального страху, через зображення недовіри до дійсності та атмосфери повсюдного стеження.

Частковий відхід німецького кінематографа 1920-х років від зображення пригодницької кінофантастики та похмура стилістика уможливили подальші творчі експерименти у фантастичному кінематографі, що зумовило створення Ф. Лангом фільму «Метрополіс» (Metropolis; 1926), котрий став першою кінематографічною антиутопією. Цей фільм був створений у новій, модерній парадигмі кінематографа, проте містив багато рис реалістичної парадигми $[11,20]$, що, зокрема, спричинило специфічне зображення соціальних антагонізмів у ньому. Так, основний конфлікт у фільмі розгортається довкола надмірної експлуатації робітників, що було звичним явищем для європейських країн того часу. 3 іншого боку, таке протистояння було перенесене у фантастичне місто Метрополіс, що, з одного боку, додало екзотичності місцю дії, а з іншого - зображувало можливі шляхи дальшого розвитку цивілізації. Одночасно з цим, перенесення наявних суспільних проблем у фантастичне місце дії уможливило їхню гіперболізацію, вибудувану на протиставленні робітничого класу, що робить підкреслено важку роботу, з панівним класом, який проводить час у дозвіллі і розвагах. Таке розмежування було наголошене за рахунок демонстрації у кінокартині футуристичної архітектури, котра одночасно маркує фантастичність зображуваного міста й акцентує суспільну нерівність через зображення різниці в умовах життя двох класів. Відповідно до названих кінематографічних прийомів було створено зображення суспільства майбутнього, у якому домінували вкрай негативні тенденції розвитку. 
Прокат «Метрополісу» не приніс очікуваних прибутків та не покрив надзвичайно великий бюджет цієї картини через те, що був занадто інтелектуальним для пересічного глядача, але недостатньо концептуальним для інтелектуальної публіки $[8,207]$. Стрічка була сприйнята неоднозначно і $з$ політичної точки зору: з одного боку, пізніше вона зазнала суттєвої цензури від націонал-соціалістів, через що 3 картини вирізали частину епізодів, а його новий фільм «Заповіт доктора Мабузе» (Das Testament des Dr. Mabuse; 1933), який був продовженням першого фільму про цього персонажа, був повністю заборонений. 3 іншого - керівні особи націонал-соціалістичної партії (Гітлер та Геббельс) особисто бачили «Метрополіс» і, відповідно до власних вражень, пропонували режисерові Лангу зайнятися постановкою нацистських стрічок $[4,80]$. Отож можна зробити припущення, що політиці нацизму частково суперечило відкрите послання картини, натомість естетика антиутопії частково перехрещувалась 3 естетикою націонал-соціалізму, через що очільники націонал-соціалістичної партії бачили у відтворенні подібної естетики пропагандистський потенціал.

Після «Метрополісу» німецький експресіонізм згасає, поступаючись місцем «Новому реалізму», а згодом - пропагандистським фільмам Третього Рейху. Естетичні напрями кінематографа інших країн не сприяли появі фільмів антиутопій у зазначений період. Винятком став британський кінематограф кінця 1920-х — початку 1930-х років, що активно запозичував здобутки німецької кінофантастики [9, 7], зокрема, великий вплив «Метрополіс» справив на фантастичну політичну картину «Державна зрада» (High Treason; 1929) [9, 24-25]. У 1936 році з'являється фільм «Прийдешнє» (Things to Come) за сценарієм одного 3 найвідоміших фантастів того часу Г. Веллса, що базувався на його ж літературних творах. В естетичному та ідеологічному аспекті «Прийдешнє» мало багато спільних рис 3 «Метрополісом», проте водночас протиставлялося йому, що було викликано, зокрема, персональним невдоволенням Веллса німецькою картиною $[9,23]$.

«Прийдешнє» містило зображення як утопічного суспільства, так і антиутопічного: за хронологією розвитку уявного майбутнього спершу цивілізація гинула внаслідок нової світової війни, а на iï руїнах виникали дрібні режими військових вождів, що досягали влади, спираючись на силу та невігластво решти людей. Натомість подібні негативні суспільно-політичні тенденції долаються у пізніший, продемонстрований у фільмі, історич- ний період, у якому завдяки діяльності науковців, які вижили, людство об'єднується у єдину утопічну технократичну республіку та забезпечує можливості для життя та розвитку кожного індивіда.

Так само, як і «Метрополіс», «Прийдешнє» також провалилося у прокаті $[9,7]$, тож можна зробити висновки щодо малої зацікавленості аудиторії фільмами-антиутопіями у період до Другої світової війни. Додатковим чинником низької популярності «Прийдешнього» виступало несприйняття аудиторією самого образу утопії, запропонованого Веллсом: ознаки фашизму протежувалися не лише в антиутопічному за своїм задумом вождівському режимі, а й у керованій технократами псевдоутопічній республіці. Критику мрій про технократію як можливого джерела фашизму провадив на прикладі Веллса, зокрема, і письменник Дж. Оруелл $[17,152]$ - автор двічі екранізованої в пізніший період антиутопії «1984».

У 1930-ті роки жанр кінофантастики популяризується лідером світового кіновиробництва США. Зокрема, з винаходом звукового кіно та виходом кінострічок «Франкенштейн» (Frankenstein; 1931) та «Дракула» (Dracula; 1931) популярності зажив жанр фільму жахів [18, 1-2]. На противагу фільмові «Дракула», що експлуатував відчуття жаху перед містичними створіннями, «Франкенштейн», так само, як і суттєва частина фільмів жахів, котрі з'явилися пізніше, використовував страх перед можливими науково-технічними відкриттями. Істотною рисою фільмів жахів науково-технічного походження у зазначений період була індивідуальна відповідальність антагоніста фільму за негативні результати фантастичних відкриттів: такий антагоніст здебільшого зображувався «божевільним вченим», який не мав жодних релігійних або моральних переконань, що могли б завадити йому користуватися своєю працею для здобуття влади або вчинення шкоди суспільству $[13,6-7]$. Натомість ідея невдалої суспільно-політичної системи, що призводила до негативних наслідків, була непопулярною та отримала розвиток лише у пізніший період. Істотному підвищенню популярності фантастичного кіно також сприяла поява фантастичного серіалу «Флеш Гордон» (Flash Gordon; 1936), базованого на однойменній серії коміксів, що викликав велику кількість наслідувань $[10,32]$. Цей серіал містив мотиви боротьби головного героя проти диктаторської влади Мінга, імператора планети Монго. 3 одного боку, імператорська влада над планетою зображувалася схожою на уявлення про екзотичні для глядача східні країни 3 деспотичним державним 
устроєм. 3 іншого - задля укріплення власної влади Мінг активно використовував фантастичні науково-технічні досягнення, хоча так само, як і у фільмах жахів, негативні наслідки використання технічних засобів спричинювалися злою волею окремого індивіда.

Наступний період підвищення популярності фантастичного кіно припадає на 1950-ті роки, що збігається з суттєвими змінами у тематиці та стилістиці фільмів. Зокрема, сюжети фантастичного кіно стають дедалі інтелектуальнішими, що сприяло появі більшої кількості фільмів з соціально-політичним посланням. 3 іншого боку, нові політичні виклики «Холодної війни», що постали перед демократичними країнами Європи та Північної Америки у повоєнний період, актуалізували тему протистояння можливій агресії соціалістичних країн, а винайдення ядерної зброї не лише підсилює таке занепокоєння, а й породжує новий страх знищення цивілізації або всього живого на Землі цією зброєю. Проявами подібних страхів були не лише фільми, у яких ядерна війна зображувалась напряму, а й такі, в яких Земля ставала жертвою вторгнення інопланетної цивілізації, що інколи інтерпретувалося в ключі фантастичного зображення світової війни [8, 15-17]. Проте обидва типи фільмів поступово змінювали акценти у репрезентації тих, через кого цивілізація зазнавала катастрофи.

Наука та науковці були частково реабілітовані у фантастичних фільмах 1950-х через використання образу благородного вченого, що бореться за порятунок людства, зокрема, у таких картинах, як «Годзилла» (ゴジラ; 1954) та «Муха» (The Fly; 1958). Натомість негативними персонажами дедалі частіше виступають політики та військові, що користуються недоліками владної вертикалі та науковими здобутками вчених задля досягнення власних цілей $[8,121]$. Хоча комерційно орієнтоване кіно не сприяло радикальній критиці панівної політичної системи, акцент фантастичного кіно був зміщений у напрямі зображення недоліків самої політичної системи, що могла зумовити нові війни, натомість мотив персональної відповідальності окремого індивіда за вчинені злочини простежується слабше відносно фільмів 1930-х років. Крім цього, фільми 1950 -х років відрізняв більший масштаб шкоди, завданої цивілізації, ніж більш рання кінофантастика, що зображала переважно локальні руйнування. Використання тематики ядерної війни давало змогу створювати дуже похмурий в естетичному плані образ майбутнього, що потім було використано у більш пізніх фільмах-антиутопіях, які часто використовували світ, що утворився внаслідок ядерної війни, як місце розгортання власного сюжету.

3 іншого боку, такі кінокартини, відповідно до модерної парадигми, у якій були створені, містили мотив можливого подолання негативних тенденцій суспільно-політичного розвитку людства. Зокрема, фільми про атомну війну мали застереження щодо можливості саме такого розвитку майбутнього людства та закликали не допустити цього. В рамках такої тенденції фантастичного кіно у Великобританії у 1956 році була екранізована антиутопія «1984», що вважалась однією з «класичних» антиутопій [2, 274], проте, на відміну від фільмів про небезпеку атомної війни, «1984» застерігав про можливість постання тоталітарної диктатури. Названа кінокартина мала також істотну відмінність від попередніх антиутопій, оскільки не містила зображення перемоги над режимом, натомість наприкінці фільму закадровий голос промовляє про можливу небезпеку постання подібного майбутнього за умови бездіяльності у теперішньому.

Тематика соціальної фантастики та антиутопії й у наступне десятиліття була відносно популярною у британському кіно, зокрема через те, що британське кіно, на відміну від американського, було менш антикомуністичним та більш контроверсійним щодо зображення політичного консенсусу у повоєнному світі $[9,1]$, а це надавало ширші можливості для соціальної критики у фільмах та, відповідно, і до створення антиутопій. Поряд з більш схожими на американські зразки фантастики кінокартинами, зокрема про нашестя монстрів або інопланетян, у Великобританії випускалися фільми, близькі до антиутопії, скажімо, стрічки «Прокляті» (The Damned; 1963), що базувала свій сюжет на секретній англійській лабораторії де виховують дітей, які житимуть у світі після неминучої ядерної війни майбутнього, та «Це сталося тут» (It Happened Here; 1965), що зображувала альтернативну історію, у якій Третій Рейх окуповував Британські острови та впроваджував підконтрольний собі тоталітарний режим. У 1966 році у Великобританії була екранізована антиутопія письменника Р. Бредбері «451 за Фаренгейтом» (Fahrenheit 451), створена режисером Ф. Трюффо. Автор літературного твору був американцем, на додачу до цього, дія як роману, так і його екранізації відбувалася у США гіпотетичного майбутнього, проте через більшу консервативність американського кінематографа цього періоду, роман виявився більш сприйнятним для адаптації саме у Великобританії. 
Серед фантастичного кіно 1960-х окремо стоїть антиутопія французького режисера Ж.-Л. Годара «Альфавіль» (Alphaville; 1965). На відміну від інших режисерів, Годар не ставив за мету комерційну успішність власних фільмів, протиставляючи себе натомість голлівудській системі кінематографа. Повний розрив режисера зі структурою наративного кіно стався наприкінці 1960-х [15, 145-146], проте вже «Альфавіль» виявляе окремі елементи, що пізніше стали виокремлюватись як специфічний стиль Годара. Зокрема, до таких особливостей, наявних у «Альфавілі», можна віднести перервність наративу, багатоскладовий дієгезис, частковий відхід від концепції принесення задоволення глядачеві та складання фільму зі щільного цитування інших творів $[19,500]$. Натомість фантастичні елементи фільму $є$ умовними: скажімо, актори використовують звичайні побутові предмети так, ніби вони є фантастичними технологічними винаходами. Відповідно до цього «Альфавіль» не зображував конкретних варіантів розвитку людства та не клопотався критикою сучасних йому соціально-політичних стосунків у звичний для антиутопії спосіб - через сюжет фільму, а мав на меті пошук нової критики форми кіно, для чого антиутопія виявилася сприятливим жанром.

Натомість перша американська кінокартина, що мала ознаки антиутопії $[12,146]$ — «Планета мавп» (Planet of the Apes; 1968), знята режисером-новатором Ф.Шаффнером, мала набагато більше рис комерційного кінематографа, ніж європейські фільми-антиутопії. Дія цієї кінокартини, так само як і великої кількості пригодницьких фантастичних стрічок більш раннього періоду, розгорталась у інопланетному середовищі, що нагадувало екзотичні східні країни, проте містила набагато більше епізодів, котрі зображують відкрите гноблення, що його героям фільму неможливо уникнути. Також наприкінці фільму протагоніст з'ясовує, що планета, на якій відбувалася дія кінострічки, насправді є Землею майбутнього, де людська цивілізація знищила себе внаслідок атомної війни, а мавпи отримали можливість еволюціонувати та створили власну цивілізацію, що гнобить людей, які вижили. Отож «Планета мавп» виявилася перехідним фільмом, що містив ознаки фантастичного кінематографа модерної парадигми - застереження щодо небезпеки атомної зброї та знищення цивілізації, а також вказував на сучасні йому проблеми расового гноблення, проте певною мірою став першим фільмом, що відкрив можливості комерційного успіху для фільмів-антиутопій, популяризувавши зазначену тематику та естетику $[16,224]$.
Це в свою чергу було активно використано кіноіндустрією у пізніші роки, особливо з утвердженням постмодерної парадигми та дедалі збільшуваного запиту аудиторії на подібні стрічки.

Таким чином, фільми-антиутопії 1920-х1960-х років були порівняно рідкісним явищем, яке виходило за рамки звичних сюжетів фантастичного кіно, що у цей період більше перетиналося 3 пригодницькими фільмами та фільмами жахів, або експлуатувало теми атомної війни чи інопланетного вторгнення. Поява фільмів-антиутопій даного періоду пов'язана зі специфічними культурно-політичними особливостями країн їхнього виробництва (насамперед, Німеччина (періоду Веймарської республіки) та Великобританія), що уможливлювали творчі експерименти у фантастиці. Антиутопії в цей період мали відносно малий комерційний успіх, хоча над їх створенням часто працювали режисери, котрі внесли вагомий вклад до розвитку кінематографа (Ф. Ланг, В. К. Мензіс, Ф. Трюффо, Ж.-Л. Годар, Ф. Шаффнер). Відповідно, жанр антиутопії цього періоду можна вважати відносно інтелектуальною та новаторською частиною фантастичного кіно, що виходила за рамки масово-орієнтованої фантастики.

\section{Джерела та література}

1. Айснер Л. Демонический экран. / Л.Айснер ; пер. с нем. К. Тимофеева. - M. : Rosebud Publishing, Пост Модерн Текнолоджи, 2010. - $240 \mathrm{c.}$

2. Баталов Э. В мире утопии: Пять диалогов об утопии, утопическом сознании и утопических экспериментах / Э. Баталов. - М. : Политиздат, 1989.-319 с.

3. Кагарлицкий Ю. Что такое фантастика? / Ю. Кагарлицкий - М : Художественная литература, 1974. - 352 c.

4. Кракауер 3. Від Калігарі до Гітлера. Психологічна історія німецького кіна / З. Каракауер. ; пер. 3 нім. І. Андрущенка. — К. : Грані-Т, 2009. — 384 с.

5. Стасюк Д. Розвиток теми утопічного майбутнього в радянській кінофантастиці 1920-1960-х років. / Д. Стасюк// Студії мистецтвознавчі - 2016. - 3 (55). - С. 72-79.

6. Фільм жахів. Горор / [ред. Фоссен У., Войтенко В.]. — К. : КІNО-КОЛО, 2005. - $504 \mathrm{c}$.

7. Фромм Э. Бегство от свободы. / Э. Фромм ; пер. с англ. А. Гуревич. - М. : Прогресс, 1990. - 272 с.

8. Ханютин Ю. Реальность фантастического мира. / Ю. Ханютин. - М. : Искусство, 1974. — 304 с.

9. British Science Fiction Cinema / British Popular Cinema [ed. by Hunter I. Q.]. — London : Routledge. 2001. — 218 p.

10. Cline, W. In the Nick of Time. Motion picture sound serials. / W. C. Cline. - London : McFarland \& Company, 1984. $285 \mathrm{p}$.

11. Coates, P. The Gorgon's Gaze : German Cinema, Expressionism, and the Image of Horror / P. Coates. Cambridge : Cambridge University Press, 1991. - 287 p.

12. Greene, E. Planet of the Apes As American Myth : Race, Politics, and Popular Culture / E. Greene,R. Slotkin. Middletown : Wesleyan University Press, 1998. - 250 p.

13. Grunzke, A. Educational institutions in Horror Films. A history of Mad Professors, Student Bodies, and Final 
Exams. / A. L. Grunzke. - New York : Palgrave McMillan, 2015. - $204 \mathrm{p}$.

14. Jameson, F. Signatures of the Visible. / F. Jameson. London : Routledge, 1992. - $254 \mathrm{p}$.

15. MacBean, J.Vent d'Est, or Godard and Rocha At The Crossroads /J. R. MacBean // Sight and Sound. — 1971. -Vol. 3 (40). - P. 144-150.

16. Neale, S. Epics, Spectacles, and Blockbusters : A Hollywood History /S. Neale, S. Hall. — Detroit : Wayne State University Press, 2010. - $376 \mathrm{p}$.

17. Orwell, G. All art is propaganda : critical essays / G. Orwell, K. Gessen [ed. by Packer, G.]. - Boston : Mariner books, 2009. - $381 \mathrm{p}$.

18. Spadoni, R. Uncanny Bodies. The coming of the sound film and the origins of the horror genre / R. Spardoni. - Berkeley : University of California press, 2007. - $204 \mathrm{p}$.

19. Wollen, P. Godard and Counter Cinema: Vent d'Est./ P. Wollen// Movies and Methods. - Vol. II. [Ed. by Bill Nichols]. - Berkeley : University of California Press, 1985. - P. 500-509.

\section{References}

1. Aysner, L. Demonicheskiy ekran. / L. Aysner ; per. s nem. K. Timofeeva. - M. : Rosebud Publishing, Post Modern Teknolodzhi, 2010. - $240 \mathrm{~s}$.

2. Batalov, E. V mire utopii: Pyat dialogov ob utopii, utopicheskom soznanii i utopicheskih eksperimentah / E. Batalov. - M. : Politizdat, 1989. - 319 s.

3. Kagarlitskiy, Yu. Chto takoe fantastika? / Yu. Kagarlitskiy. M : Hudozhestvennaya literatura, 1974. - $352 \mathrm{~s}$.

4. Krakauer, Z. Vid Kalihari do Hitlera. Psykholohichna istoriia nimetskoho kina / Z. Karakauer. ; per. z nim. I. Andrushchenka. - K. : Hrani-T, 2009. - 384 s.

5. Stasiuk, D. Rozvytok temy utopichnoho maibutnoho v radianskii kinofantastytsi 1920-1960-kh rokiv. / D. Stasiuk// Studii mystetstvoznavchi - 2016. - 3 (55). — S. 72-79.

6. Film zhakhiv. Horor / [red. Fossen U., Voitenko V.]. - K. : KINO-KOLO, 2005. - $504 \mathrm{~s}$.
7. Fromm, E. Begstvo ot svobodyi. / E. Fromm ; per. s angl. A. Gurevich. - M. : Progress, 1990. - $272 \mathrm{~s}$.

8. Hanyutin, Yu. Realnost fantasticheskogo mira. / Yu. Hanyutin. - M. : Iskusstvo, 1974. - $304 \mathrm{~s}$.

9. 9. British Science Fiction Cinema / British Popular Cinema [ed. by Hunter I. Q.]. — London : Routledge. 2001. — 218 p.

10. Cline, W. In the Nick of Time. Motion picture sound serials. / W. C. Cline. - London : McFarland \& Company,1984. $285 \mathrm{p}$.

11. Coates, P. The Gorgon's Gaze : German Cinema, Expressionism, and the Image of Horror / P. Coates. Cambridge : Cambridge University Press, 1991. $287 \mathrm{p}$.

12. 11. Greene, E. Planet of the Apes As American Myth : Race, Politics, and Popular Culture / E. Greene,R. Slotkin. Middletown : Wesleyan University Press, 1998. $250 \mathrm{p}$.

13. 12. Grunzke, A. Educational institutions in Horror Films. A history of Mad Professors, Student Bodies, and Final Exams. / A. L. Grunzke. - New York : Palgrave McMillan, 2015. $-204 \mathrm{p}$.

14. Jameson, F. Signatures of the Visible. / F. Jameson. London : Routledge, 1992. - $254 \mathrm{p}$.

15. 14. MacBean, J. Vent d'Est, or Godard and Rocha At The Crossroads /J. R. MacBean // Sight and Sound. - 1971. - Vol. 3 (40). - P. 144-150.

16. Neale, S. Epics, Spectacles, and Blockbusters : A Hollywood History/S. Neale, S. Hall. — Detroit : Wayne State University Press, 2010. - $376 \mathrm{p}$.

17. Orwell, G. All art is propaganda : critical essays / G. Orwell, K. Gessen [ed. by Packer, G.]. — Boston : Mariner books, 2009. - $381 \mathrm{p}$.

18. Spadoni, R. Uncanny Bodies. The coming of the sound film and the origins of the horror genre / R. Spardoni. - Berkeley : University of California press, 2007. - $204 \mathrm{p}$.

19. Wollen, P. Godard and Counter Cinema: Vent d'Est./ P. Wollen// Movies and Methods. - Vol. II. [Ed. by Bill Nichols]. - Berkeley : University of California Press, 1985. - P. 500-509. 